\title{
Identification of Strain MF861-C4, a Kasugamycin-Producing Actinomycete, as Streptomyces albulus
}

\author{
Naoko Kinoshita, Seiko Hattori, Souichi Ikeno ${ }^{1}$, Makoto Hori ${ }^{1}$ and Masa Hamada
}

Institute of Microbial Chemistry, 14-23, Kamiosaki 3-chome, Shinagawa-ku, Tokyo 141, Japan and 'Showa College of Pharmaceutical Sciences, 3-3165 Higashi Tamagawagakuen, Machida-shi, Tokyo 194, Japan

\section{(Received Oct. 24, 1996 / Accepted Nov. 18, 1996)}

We isolated a kasugamycin-producing actinomycete, strain MF861-C4, which had spiny spore surface. This strain was different from Streptomyces kasugaensis ${ }^{1}$ but rather close to Streptomyces albulus with regard to morphological, cultural, and physiological characteristics, DNA homology and partial base sequences of $16 \mathrm{~S}$ ribosomal RNA. The strain MF861-C4 was identified as $S$. albulus.

We isolated several actinomycete strains producing kasugamycin, such as M338-M1, MB273-C4, and MF861-C41,2). We previously reported that strains M338-M1 and MB273-C4 should belong together to a new species of the genus Streptomyces and officially proposed the name Streptomyces kasugaensis, the type strain being M338-M1 (= ATCC 15714) $)^{1}$. In the present paper we report that strain MF861-C4 is different from $S$. kasugaensis but rather close to S. albulus with regard to morphological, cultural, and physiological characteristics, and DNA homology.

The strain MF861-C4 was isolated from a soil sample collected at the ground of Tenmanguh shrine, Katsunuma-cho, Higashiyamanashigun, Yamanashi prefecture, Japan in 1977. Methods of taxonomic and genetic studies were described in the previous paper ${ }^{1}$.

\section{Morphological characteristics}

Strain MF861-C4 formed well-branched vegetative mycelia and formed long aerial hyphae which bore complete spirals of 5 or more turns. Mature spore chains consisted of 10 or more spores. The spores were oval ( 0.3 to 0.5 by 0.6 to $0.8 \mu \mathrm{m}$ ) and not motile and their surfaces were spiny (Fig. 1). No synnemata, sclerotia or sporangia were observed.

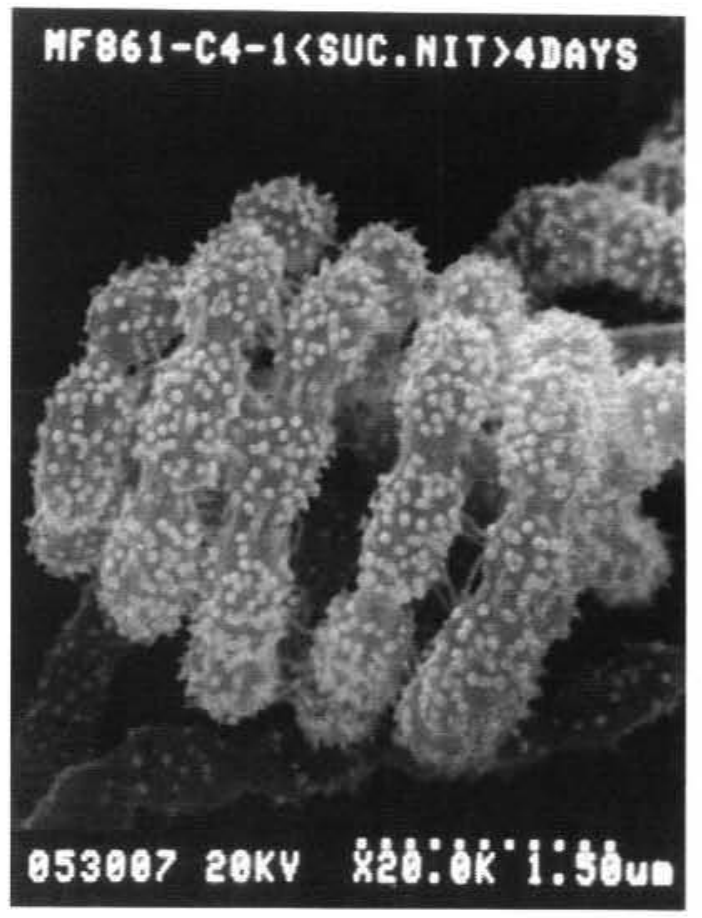

Fig. 1. Scanning electron micrograph of strain MF861-C4 grown on sucrose-nitrate agar at $27^{\circ} \mathrm{C}$ for 4 days. 
Table 1. Cultural characteristics of strain MF861-C4

\begin{tabular}{|c|c|c|c|}
\hline Medium & Growth & Aerial mycelium & Soluble pigment \\
\hline Sucrose-nitrate agar & Colorless & Thin, Natural [2 dc] & None \\
\hline $\begin{array}{l}\text { Yeast extract- } \\
\text { malt extract agar } \\
\text { (ISP No.2) }\end{array}$ & Bamboo $[2 \mathrm{gc}] \sim \mathrm{Lt} \operatorname{Tan}[3 \mathrm{gc}]$ & White & None \\
\hline $\begin{array}{l}\text { Oatmeal agar } \\
\text { (ISP No.3) }\end{array}$ & $\begin{array}{l}\text { Cream }\left[\begin{array}{ll}1 & 1 / 2 \mathrm{ca}\end{array}\right] \sim \\
\text { Lt Ivory [2 ca] }\end{array}$ & $\begin{array}{l}\text { Silver Gray [3 fe] } \\
\text { Rose Taupe[5 ig] }\end{array}$ & None \\
\hline $\begin{array}{l}\text { Inorganic salts- } \\
\text { starch agar (ISP } \\
\text { No.4) }\end{array}$ & Bamboo $[2 \mathrm{gc}] \sim \mathrm{Lt} \operatorname{Tan}[3 \mathrm{gc}]$ & $\begin{array}{c}\text { White } \sim \text { Covert Gray }[2 \mathrm{fe}] \\
\sim \text { Silver Gray }[3 \mathrm{fe}]\end{array}$ & None \\
\hline $\begin{array}{l}\text { Glycerol-asparagine } \\
\text { agar (ISP No.5) }\end{array}$ & Mustard [2 le] $\sim$ Lt Tan $[3 \mathrm{gc}]$ & $\begin{array}{l}\text { Covert Gray }[2 \mathrm{fe}] \sim \\
\text { Silver Gray }[3 \mathrm{fe}]\end{array}$ & Faint, brownish \\
\hline $\begin{array}{l}\text { Tyrosine agar } \\
\text { (ISP No.7) }\end{array}$ & $\begin{array}{l}\text { Lt Amber }[3 \text { ic }] \sim \\
\text { Cinnamon }[3 \text { le }]\end{array}$ & White Covert Gray [ 2 fe] & Faint, brownish \\
\hline $\begin{array}{l}\text { Glucose-asparagine } \\
\text { agar }\end{array}$ & Lt Wheat [ 2 ea] & $\begin{array}{c}\text { White } \sim \text { Silver Gray }[3 \mathrm{fe}] \\
\sim \text { Ashes }[5 \mathrm{fe}]\end{array}$ & Faint, yellowish \\
\hline Nutrient agar & Lt Wheat [ 2 ea] & Thin, white & None \\
\hline Starch agar & Lt Yellow $\left[\begin{array}{ll}1 & 1 / 2 \mathrm{ea}\end{array}\right]$ & White & Faint, yellowish \\
\hline Calcium-malate agar & Colorless & Thin, white & None \\
\hline
\end{tabular}

Observation after incubation at $27^{\circ} \mathrm{C}$ for 21 days.

Color names and numbers from Color Harmony Manual, Container Corporation of America.

For methods, see reference 1 .

\section{Cultural and physiological characteristics}

The cultural characteristics of strain MF861$\mathrm{C} 4$ on various agar media are shown in Table 1 . The aerial mycelia were white to light gray. The vegetative mycelia were pale yellow to pale yellowish brown. This strain produced faintly yellowish to brownish soluble pigments on several media. Physiological characteristics and carbohydrate utilization are shown in Table 2. Permissive temperatures for growth ranged from $20^{\circ} \mathrm{C}$ to $37^{\circ} \mathrm{C}$, with the optimal temperatures between $27^{\circ} \mathrm{C}$ and $30^{\circ} \mathrm{C}$.

\section{Chemotaxonomic characteristics}

Whole-cell hydrolysates contained LL-diaminopimelic acid, but no detectable arabinose, galactose, or meso-diaminopimelic acid. Phospholipid pattern was type PII; phosphatidylinositol and phosphatidylethanolamine were present but none of phosphatidylmethylethanolamine, phosphatidylcholine, or unknown glucosamine-containing phospholipid was found. Mycolic acids were absent. Major menaquinones were MK-9 $\left(\mathrm{H}_{4}\right)$ and MK-9 $\left(\mathrm{H}_{6}\right)$. Cellular fatty acids consisted of iso-branched 14-meth- 
Table 2. Physiological characteristics of strain MF861-C4

\begin{tabular}{cc}
\hline $\begin{array}{l}\text { Temperature range for growth }\left({ }^{\circ} \mathrm{C}\right) \\
\text { Optimum temperature }\left({ }^{\circ} \mathrm{C}\right)\end{array}$ & $20 \sim 37$ \\
Formation of melanoid pigment & $27 \sim 30$ \\
ISP No.1 & Negative \\
ISP No.6 & Negative \\
ISP No.7 & Negative \\
Liquefaction of & \\
gelatin & Positive \\
glucose peptone gelatin & Positive \\
Coagulation of milk & Positive \\
Peptonizatin of milk & Positive \\
Hydrolysis of starch & Positive \\
Reduction of nitrate & Variable \\
Utilization of & \\
L-Arabinose & - \\
D-Xylose & - \\
D-Glucose & - \\
D-Fructose & + \\
Sucrose & + \\
Inositol & + \\
Rhamnose & \\
Raffinose & - \\
D-Mannitol & + \\
\hline
\end{tabular}

+ : Utilization, - : No utilization

For method, see reference 1.

ylpentadecanoic acid ( $i-16: 0)$, anteiso-branched 12-methyltetradecanoic acid (ai-15:0), isobranched 13-methyltetradecanoic acid (i-15:0), anteiso-branched 14-methylhexadecanoic acid (ai-17:0), and other minor components. The $\mathrm{G}+\mathrm{C}$ contents of DNA was $70.9 \mathrm{~mol} \%$.

\section{Identity of strain MF861-C4}

The taxonomic properties given above suggested that strain MF861-C4 belonged to the genus Streptomyces. We searched the taxonomic data of known Streptomyces species in the ISP descriptions by Shirling and Gottlieb ${ }^{3-6}$ and in the descriptions of Streptomyces species in the International Journal of Systematic Bacteriology since 1980. The search showed that strain MF861-C4 was most closely related to $S$. albu$l u s^{6}$. S. albulus is listed as an allied species of Streptomyces lydicus in the Bergey's Manual of Systematic Bacteriology ${ }^{7}$. Strain MF861-C4 was therefore compared with $S$. albulus IMC A$0802^{\mathrm{T}}$ (ISP 5492) and S. lydicus IMC S-0321 ${ }^{\mathrm{T}}$ (ISP 5461), both of which had been maintained at the Institute of Microbial Chemistry. As shown in Table 3, the morphological, cultural and physiological characteristics of strain MF861-C4 were similar to those of S. albulus except that the latter did not produced kasugamycin. On the other hand, strain MF861-C4 was different from S. lydicus in that the latter had smooth spore surface and utilized L-arabinose and raffinose. Major menaquinones and fatty acid compositions of strain MF861-C4 were quantitatively different from those of $S$. albulus. DNA homology between strain MF861-C4 and S. albulus was relatively high (50 79\%) while that between strain MF861-C4 and S. lydicus was low (26\%). Our results of these taxonomic studies and DNA homology, incidentally, suggested that $S$. albulus is not allied species of S. lydicus.

The base sequences between 121st and 240th $\left(V_{2}\right.$ region, where the high base replacement frequency is observed) of $16 \mathrm{~S}$ ribosomal RNA genes of strain MF861-C4 and S. albulus were identical to each other, while they were different from that of $S$. kasugaensis in 8 bases (Fig. 2). Some genetic instability of strain MF861-C4 was noticed ${ }^{2}$.

Taken together, we conclude that strain MF861-C4 is a member of Streptomyces albulus and propose name it Streptomyces albulus 
Table 3. Comparison of strain MF861-C4, Streptomyces albulus and S. lydicus

\begin{tabular}{|c|c|c|c|}
\hline & Strain MF861-C4 & $\begin{array}{l}\text { Streptomyces albulus } \\
\text { IMC S-0802 } \\
\text { (ISP 5492) }\end{array}$ & $\begin{array}{l}\text { S. lydicus } \\
\text { IMC S-0321 }^{\mathrm{T}} \\
\text { (ISP 5461) }\end{array}$ \\
\hline Spore chain & Spirales & Spirales & Spirales \\
\hline Spore surface & Spiny & Spiny & Smooth \\
\hline Aerial mycelium & White $\sim$ light gray & Light gray & White $\sim$ light gray \\
\hline Substrate mycelium & $\begin{array}{c}\text { Pale yellow } \sim \\
\text { pale yellowish brown }\end{array}$ & Pale yellow & $\begin{array}{l}\text { Colorless } \\
\text { pale yellow }\end{array}$ \\
\hline Soluble pigment & None & None & None \\
\hline Formation of melanoid pigment & Negative & Negative & Negative \\
\hline Liquefaction of gelatin & Positive & Positive & Positive \\
\hline Coagulation of milk & Positive & Positive & Positive \\
\hline Peptonization of milk & Positive & Positive & Positive \\
\hline Hydrolysis of starch & Positive & Positive & Positive \\
\hline Reduction of nitrate & Variable & Positive & Negative \\
\hline \multicolumn{4}{|l|}{ Utilization of } \\
\hline D-Glucose & + & + & + \\
\hline L-Arabinose & - & - & + \\
\hline D-Xylose & - & - & \pm \\
\hline D-Fructose & + & + & + \\
\hline Sucrose* & - & - & - \\
\hline Inositol & + & + & + \\
\hline Rhamnose & - & - & - \\
\hline Raffinose & - & - & + \\
\hline D-Mannitol & + & + & + \\
\hline Lactose & - & - & + \\
\hline Production of kasugamycin & Positive & Negative & Negative \\
\hline
\end{tabular}

For method, see reference 1 


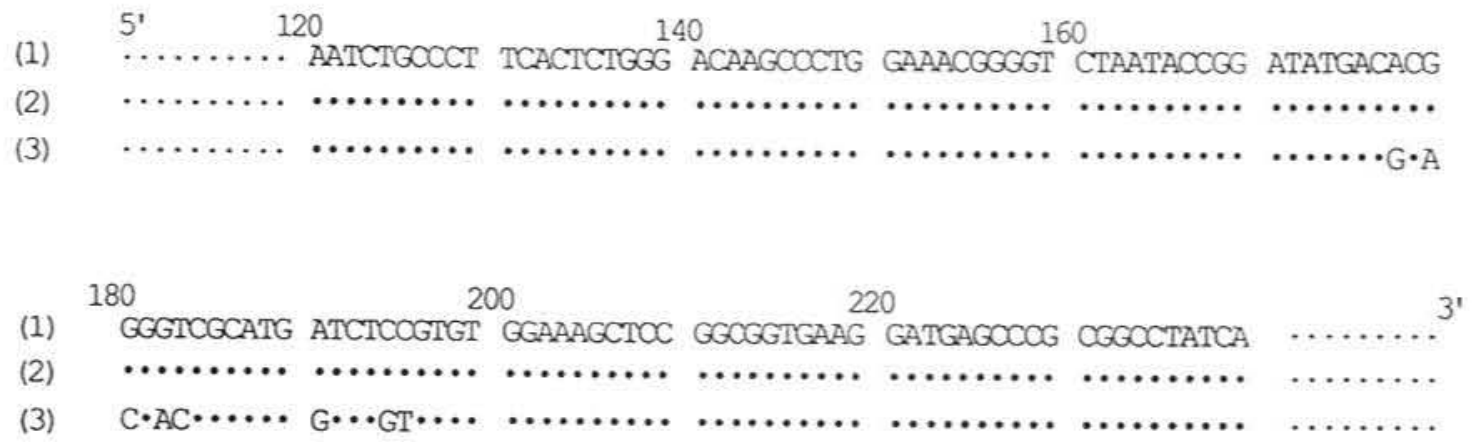

Fig. 2. Nucleotide sequences of $16 \mathrm{~S}$ rRNA gene.

These nucleotide sequences of the $16 \mathrm{~S}$ rRNA gene correspond to the $\mathrm{V}_{2}$ region (120 bp).

(1) S. sp. MF-861-C4 (2) S. albulus IMC S-0802 (ISP 5492) (3) S. kasugaensis M338-M1

MF861-C4. A subculture of strain MF861-C4 was submitted to the National Institute of Bioscience and Human-Technology, the Agency of Industrial Science and Technology, Tsukuba, Japan, under the accession No. FERM P-15912.

\section{ACKNOWLEDGMENTS}

The authors are grateful to Dr. Tsuyoshi Tamamura, Central Research Laboratories, Hokko Chemical Industries Co. Ltd. for the analyses of fatty acids.

\section{REFERENCES}

1)Hamada, M.; N. Kinoshita, S. Hattori, A. Yoshida, Y. Okami, K. Higashide, N. Sakata \& M. Hori: Streptomyces kasugaensis sp. nov.: A new species of genus Streptomyces. Actinomycetol. 9: 27-36, 1995.

2)Ikeno, S.; K. Higashide, M. Hori, N. Kinoshita \& M. Hamada: Correlation between the presence of $k a c$, kasugamycin acetyltransferase gene, and the productivity of kasugamycin in Streptomyces. Actinomycetol. 10: 73-79, 1996.
3)Shirling, E. B. \& D. Gottlieb: Cooperative description of type cultures of Streptomyces. II. Species descriptions from first study. Int. J. Syst. Bacteriol. 18: 69-189, 1968.

4)Shirling, E. B. \& D. Gottlieb: Cooperative description of type cultures of Streptomyces. III. Additional species descriptions from first and second studies. Int. J. Syst. Bacteriol. 18: 279$392,1968$.

5)Shirling, E. B. \& D. Gottlieb: Cooperative description of type cultures of Streptomyces. IV. Species descriptions from the second, third and fourth studies. Int. J. Syst. Bacteriol. 19: 391-512, 1969.

6)Shirling, E. B. \& D. Gottlieb: Cooperative description of type strains of Streptomyces. V. Additional descriptions. Int. J. Syst. Bacteriol. 22: 265-394, 1972.

7)Williams, S. T,; M. Goodfellow \& G. Alderson: Genus Streptomyces Waksman and Henrici 1943, 339AL, In "Bergey's manual of systematic bacteriology, vol. 4" (ed. S. T. Williams, M. E. Sharpe \& J. G. Holt) pp.2452-2492, The Williams \& Wilkins Co., Baltimore, 1989.

8)Jacobson, E.; W. C. Granville \& C. E. Foss: Color harmony manual, 4 th ed., Container Corporation of America, Chicago, 1958. 